\title{
Mediterranean resistance in Paolo Rumiz's Il Ciclope: the island and the lighthouse
}

Silvia Caserta

\begin{tabular}{|c|c|}
\hline Date of deposit & 30102018 \\
\hline Document version & Author's accepted manuscript \\
\hline Access rights & $\begin{array}{l}\text { Copyright @ } 2018 \text { The Society for Italian Studies. This work is } \\
\text { made available online in accordance with the publisher's policies. } \\
\text { This is the author created, accepted version manuscript following } \\
\text { peer review and may differ slightly from the final published } \\
\text { version. }\end{array}$ \\
\hline $\begin{array}{l}\text { Citation for } \\
\text { published version }\end{array}$ & $\begin{array}{l}\text { Caserta, S. (2018). Mediterranean resistance in Paolo Rumiz's Il } \\
\text { Ciclope: the island and the lighthouse. Italian Studies. Latest } \\
\text { Articles. }\end{array}$ \\
\hline $\begin{array}{l}\text { Link to published } \\
\text { version }\end{array}$ & https://doi.org/10.1080/00751634.2019.1532646 \\
\hline
\end{tabular}

Full metadata for this item is available in St Andrews Research

Repository at: https://research-repository.st-andrews.ac.uk/

\section{St Andrews Research Repository}




\title{
Mediterranean Resistance in Paolo Rumiz's Il Ciclope.
}

\section{The Island and the Lighthouse.}

\begin{abstract}
Within the growing scholarly attention, in the field of Italian Studies, devoted to contemporary travel writing, on the one hand, and to writers coming from the geo-historical 'margins' of the peninsula, on the other, Paolo Rumiz's works have sparked critical interest in recent years. In contrast with the prevailing reading of Rumiz's work as mostly concerned with Eastern Europe, in this essay I assess the centrality of the Mediterranean in the author's narrative imaginary, as it emerges in Il Ciclope (2015). Drawing on geocritical and ecocritical theories, I show how Rumiz's Mediterranean island - where the real and imaginary travel of Il Ciclope takes place - narratively reveals itself as a space that comprises land and sea at the same time; a space that, while being localised, can also address global concerns, and that, from its supposedly marginal position in the global world, can become a centre of critical thinking.
\end{abstract}

Keywords: Rumiz, Mediterranean, Geocriticism, Ecocriticism, Island, Cyclops

In the field of Italian Studies, an increasing amount of attention is being devoted to contemporary travel writing, on the one hand, and to writers coming from the geo-historical 'margins' of the peninsula, on the other. In this context, Paolo Rumiz's works have sparked critical interest in recent years. ${ }^{1}$ A Triestine travel journalist, columnist and correspondent for the national newspaper La Repubblica and the local newspaper Il Piccolo, Paolo Rumiz is

\footnotetext{
${ }^{1}$ See Loredana Polezzi, Translating Travel: Contemporary Italian Travel Writing in English Translation (Aldershot: Ashgate, 2001), which takes as its starting point the - at the time - marginal position of contemporary Italian travel writing in the Italian literary system. See also Catharine Mee, Interpersonal Encounters in Contemporary Travel Writing: French and Italian Perspectives (London: Anthem Press, 2014; Cristina Perissinotto and Charles Klopp, Cronache Dal Cielo Stretto: Scrivere Il Nordest (Udine: Forum, 2013). In both works, Rumiz is one of the key authors within the selected corpus.
} 
mostly known in Italy for his reports from the Balkan region during and after the Yugoslavian war and for the narratives of his travels across Eastern Europe. ${ }^{2}$ Michał Czorycki's recent article on Rumiz's representation of Eastern Europe in $\grave{E}$ Oriente has reaffirmed Rumiz's reputation as a writer primarily interested in the West/East dichotomy as a shaping force in the construction of Europe. ${ }^{3}$

Following the recent wave of interest around Rumiz's work, I would like to suggest a shift in the perspective from which we approach it. I will diverge from the European standpoint of Czorycki's study, in order to assess the centrality of the Mediterranean in Rumiz's narrative imaginary through a focus on Il Ciclope. ${ }^{4}$ This recent book marks a departure from the writer's earlier dedication to journalism and travel writing. Although $I l$ Ciclope is apparently the report of Rumiz's journey to an unspecified Mediterranean island, the travels described are more metaphorical than physical. Narration takes precedence over description, and a division into chapters with evocative titles replaces the characteristic dayto-day entries typical of diary-style report.

Rumiz's journey thus becomes the pretext for a meditation on the Mediterranean as a specific ecological and geological space, which upends conventional geographical binaries such as West/East and North/South. Far from appearing as an unspoiled and backward space to be opposed, with either positive or negative connotations, to a modern and progressive Northern Europe, the Mediterranean that emerges from Il Ciclope is both a real and an imaginary space that is able to embrace its own contradictions. Rumiz's Cyclops' island is a local and a global space, a periphery and a centre, where fast modernity might be challenged and alternatives imagined.

\footnotetext{
${ }^{2}$ The reports originally came out in episodes for La Repubblica, and this format allowed them to reach a large and diversified audience. Only at a later stage did the author collect, revise and publish them in volume form. $L a$ linea dei Mirtilli (Rome: Editori Riuniti, 1993, 1997) and Maschere per un massacro (Rome: Editori Riuniti, 1996) describe the war scenario of the former Yugoslavia, while works such as $E$ Oriente (Milan: Feltrinelli, 2003) and Trans Europa Express (Milan: Feltrinelli, 2012) focus on the East-West division of Europe during and after the Cold War.

${ }^{3}$ Michał Czorycki, 'The Politics of Travel: Eastern Europe in Paolo Rumiz's È Oriente', Italian Studies, 69.1 (2014), 139-57.

${ }^{4}$ Paolo Rumiz, Il Ciclope (Milan: Feltrinelli, 2015).
} 


\section{Rumiz's Mediterranean Alternative}

Despite the predominant focus of Rumiz's travelogues on Europe, and Eastern Europe in particular, the Mediterranean has progressively become more visible in the author's work. $L a$ Leggenda dei Monti Naviganti (2007) and Annibale (2008) share a view of the land from the perspective of the sea, a 'pelagic perception' of the world that also informs the writer's outlook in $\mathrm{Il}$ Ciclope. ${ }^{5}$

In La Leggenda dei Monti Naviganti Rumiz narrates his travels along the Apennines, which constitute the physical backbone of the Italian peninsula. Although the author does not travel by sea, the book narrates a journey that begins and ends at sea, and is full of maritime metaphors. In the words of an Emilian woman Rumiz encounters along his way, 'gli Appennini sono una gomena legata alle Alpi, che si ancora al Mediterraneo' (p. 208). If Italy is 'aquatically' Mediterranean, the whole Mediterranean is 'uno spazio di pastori diventati capitani' (p. 20), where the agricultural landscape cannot oppose any resistance to the maritime vocation of its people.

Although the journey Rumiz undertakes on the trail of Hannibal is again not a sea voyage, Annibale opens with a map that is centred on the sea. The shapes of the seas emerge in white, with their names printed on them; the lands, by contrast, appear only in grey, which makes it difficult to identify them at first glance. These lands lack country (or continent) names, and are only marked by the names of the cities Rumiz, and Hannibal before him, passed through. Here Rumiz suggests that we look at land, and at Hannibal's journey, from the perspective of the sea. It is a suggestion that the writer fully articulates in Il Ciclope, where he foregrounds the transnational dimension of the Mediterranean.

\footnotetext{
${ }^{5}$ Paolo Rumiz, La Leggenda dei Monti Naviganti (Milan: Feltrinelli, 2007); Paolo Rumiz, Annibale (Milan: Feltrinelli, 2008). In both works, the journey takes place mostly in Italy, whose borderline and unstable position in between North and South, Europe and the Mediterranean, anticipates the instability of Il Ciclope's island.
} 
In Annibale Rumiz also offers a first articulation of his unconventional remapping of the Mediterranean. Hannibal's journey points to an upturned geography. The Carthaginian captain's enterprise rejects the traditional North/South dichotomy of the Mediterranean, since it is from the North, from the Italian Alps, that 'l'Africa invadeva l'Italia' (p. 12). It is this upside down and complicated map that Rumiz juxtaposes, as a form of resistance, to the globalised geography of the contemporary Mediterranean. Globalisation has not only put more distance between Italy and Africa, it has also marginalised the Mediterranean islands that are at the centre of Il Ciclope's narrative.

By tracing such a distinct Mediterranean geography, Rumiz's travels in La Leggenda and Annibale pave the way for Il Ciclope's real and imaginary journey. However, Il Ciclope also marks a development in the author's conception of the Mediterranean, which emerges from both the form and the content of the book. In Il Ciclope, narrative passages that focus either on Rumiz's present time on the island or on past journeys to other (mostly Mediterranean) islands alternate with descriptions of the island itself. At the same time, historical, philosophical, and literary reflections often interrupt the main narrative thread, contributing to a digressive and de-centring structure that closely resonates with Rumiz's reimagining of the Mediterranean. As I will explain in detail later, the space of the island, and of the whole Mediterranean beyond it, is unstable, fragmented, open and ambivalent. The only narrative form that can suit it must therefore also be open, elusive, and digressive.

The unstable and ambiguous shape that characterises both the formal aspects of $I l$ Ciclope and the space that the work narrates also relates to Rumiz's home town, Trieste, as a particular geographical and geopolitical space with its specific literary tradition. A border town, long part of the Habsburg Empire and annexed to Italy only at the end of the First World War,

Trieste became particularly sensitive to national, even nationalist, discourses, which tended to travel locally under the name of italianità (or Italian-ness, i.e. the essence of being Italian). 
Trieste also became prone to intensely insular, local, and even localistic discourses aimed at preserving a largely mythical and imaginary idea of a local singularity. These discourses were peddled under the name triestinità (or Triestin-ness, i.e. the essence of being Triestine). ${ }^{6}$

In its peripheral and insular condition and in the unstable balance between local and global, Trieste has constantly struggled to re-inscribe and re-affirm its multiple belongings. European, Italian, and Mediterranean, hence participating in the Mediterranean marginality of Italy vis-à-vis Europe, ${ }^{7}$ Trieste, a cosmopolitan city 'of cultural exchange and openness', ${ }^{8}$ shares its condition with the island Rumiz portrays in Il Ciclope. As Bialasiewicz argues, in the same way as 'thinking about a city like Trieste can open up new ways of thinking about Europe', ${ }^{9}$ the island Rumiz travels to can, from its marginal and peripheral position, open up ways of reimagining the Mediterranean. Born in a city where 'the lines between fact and fiction, past and present, the explicit and the enigmatic, let alone between one ethnicity and another, always seem uncertain', ${ }^{10}$ Rumiz transfers this uncertainty to his Cyclops' island, and from there to the whole Mediterranean, making it productive rather than problematic and defective.

Moreover, in its structure and style Il Ciclope follows a Mitteleuropean, but also Triestine, literary tradition that, starting with Italo Svevo at the beginning of the $20^{\text {th }}$ century, dismantles the novel's conventional plot through the insertion of a strong nonfictional and reflexive component. In the specific context of contemporary Triestine travel writing, Claudio Magris' Danubio constitutes a direct precedent for Rumiz's Il Ciclope. ${ }^{11}$ In Danubio, the narrative of Magris' human and literary journey along the eponymous river before the end of the Cold War becomes a pretext for reflecting upon the contradictions of Europe. Featuring a

\footnotetext{
${ }^{6}$ Katia Pizzi, 'Gender, Confession and Ethnicity: Women Writers and Trieste', The Journal of Romance Studies, 7.1 (2007), $71-78$ (p. 72).

${ }^{7}$ For an interesting reading of Trieste as a mirror of the European condition, see Luiza Bialasiewicz, 'Europe As/at the Border: Trieste and the Meaning of Europe', Social \& Cultural Geography, 10.3 (2009), 319-336.

${ }^{8}$ Bialasiewicz, p. 321.

${ }^{9}$ Bialasiewicz, p. 320.

${ }^{10}$ Jan Morris, Europe: An Intimate Journey (London: Faber \& Faber, 2006), p. 57.

${ }^{11}$ Claudio Magris, Danubio (Milan: Garzanti, 1986).
} 
deliberately confusing structure, between travelogue and fiction, that resembles that of $I l$ Ciclope, Danubio is a "viaggio e romanzo-saggio", that lacks references to precise days and times. The book develops instead as a narrative of journeys and experiences that belong to different times and spaces, but that the present account weaves into a composite and fictional texture. And although the river as a fundamental symbol of Mitteleuropa appears repeatedly in Magris' early essays, Danubio belongs to a late stage of the writer's career. In a similar way, Rumiz's Mediterranean alternative occurs as a late development of the author's earlier travelogues. The contradictions that the contemporary Mediterranean space both reveals and challenges require a narrative agency that goes beyond the descriptive dimension of the previous reports. In the preface to Predrag Matvejević's Mediterranean Breviary, Magris notes: 'Questo libro mediterraneo è un racconto, che fa parlare la realtà e innesta perfettamente la cultura nell'evocazione fantastica. Probabilmente oggi questo è il genere più vivo e fecondo della letteratura' ${ }^{13}$ The same could be said of Rumiz's Il Ciclope. It is a 'Mediterranean story' that brings together reality and imagination, aiming at a new theorisation of the Mediterranean itself.

\section{Re-mapping the Mediterranean}

Il Ciclope challenges any binary opposition between movement and immobility, as well as modernity and tradition, in the Mediterranean. ${ }^{14}$ The work develops instead a narrative reconfiguration of such categories in the space of a Mediterranean that subverts normative conceptions of centre-periphery relations, and where land and sea, human and non-human, can coexist. While voluntarily trapped in the lighthouse of a tiny island in the middle of the sea, the writer undertakes a narrative journey that allows him to participate in the instability,

\footnotetext{
${ }^{12}$ Luca Pocci, 'Il Fiume Della Scrittura. Viaggio e Romanzo-Saggio in Danubio di Claudio Magris', Italian Culture, 24.1 (2007), 91-112.

${ }^{13}$ Claudio Magris, 'Per una filologia del mare', in Predrag Matvejevic, Mediterraneo: un Nuovo Breviario (Milan: Garzanti, 1991), 7-11 (p. 11).

${ }^{14}$ For the Mediterranean as an alternative modernity see Iain Chambers, Sea and the City (2015), 1-3

$<$ https://zenodo.org/record/1067160\#.W6ZTdi-ZOi4> [accessed 20 September 2018]
} 
constant changes, and adaptations of the whole Mediterranean. Thus Rumiz's Mediterranean reveals itself as a space that embraces its contradictions, while struggling to resist the annihilation and oblivion to which a fast globalisation tends to relegate it - where globalisation is understood, in Jameson's terms, as the destruction of traditions that are not pre-modern and pre-capitalist, but 'successful accommodations of the old institutions to modern technology'.15

The island that Rumiz chooses as his temporary abode may at first appear to be characterised by a double layer of alterity and exoticism. The Mediterranean as a whole has long been imagined and experienced as an exotic space from a European - and Eurocentric point of view. Similarly, 'colonial narratives and the tourist industry have long depicted island space as remote, isolated, and peripheral to modernity, ${ }^{16}$ hence also fascinating and exotic. ${ }^{17}$ Rumiz gives his Mediterranean space a flavour of the Orient, while relegating to the background the southern shore, with its combined Arab and north African influence. ${ }^{18}$ At the same time, the writer's outspoken predilection for Greece reinforces a conventional Eurocentric equivalence, which links back the whole Mediterranean to ancient Greece itself. ${ }^{19}$

In this conceptual framework, it is not surprising to find scattered traces of a colonial attitude, for instance in the way in which the author approaches the spectacle of nature on the

\footnotetext{
${ }^{15}$ Fredric Jameson, 'Notes on globalization as a philosophical issue', in The Cultures of Globalization, ed. by Fredric Jameson and Masao Miyoshi (Durham: Duke University Press, 1998), pp. 54-77 (p. 63).

${ }^{16}$ Elizabeth DeLoughrey, 'Island Writing, Creole Cultures', in The Cambridge History of Postcolonial Literature, ed. by Ato Quayson (Cambridge: Cambridge University Press, 2011), pp. 802-32 (p. 802).

${ }^{17}$ This is evident when considering the wide range of traditional island literature, from Robinson Crusoe onward. On this topic, Harry Garuba notes that 'the literature of exploration, slavery, and colonialism is replete with islands' ('The Island Writes Back: Discourse/Power and Marginality in Wole Soyinka's The Swamp Dwellers, Derek Walcott's The Sea at Dauphin, and Athol Fugard's The Island', Research in African Literatures, 32.4 (2001), 61-76). Islands are also a favourite location for 'utopian' literature, as ideal places from which mainland societies can be critiqued and satirised, starting with Thomas More's Utopia (which literally means 'no place', but is in fact an island).

18 'Un vento che ha odore di Oriente' (p. 16). 'Da Levante continueremo ad attingere calore e vita' (p. 23). Although Rumiz's insistence on the Oriental character of the Mediterranean might have to do with his familiarity with the Balkan region, his disregard for the North African shore of the Mediterranean is quite striking, and affects the scope of his re-imagining of the Mediterranean.

19 'Il debito greco: mi fa ridere, a ripensarci, che semplicemente se ne parli. Debito greco! Con quello che l'Europa e il mondo devono alla Grecia!' (p. 19). And later he expresses his appreciation for the name of a promontory in Southern Italy because its name tastes like ancient Greece (p. 51). The risk of suggesting a univocal Greek origin for the whole Mediterranean also looms over Cacciari's and Cassano's Italian geophilosophy of the Mediterranean. See Massimo Cacciari, L'arcipelago (Milan: Adelphi, 1997); Franco Cassano, Il Pensiero Meridiano (Bari: Laterza, 1996).
} 
island. He adopts a perspective that Sara Mills, in her study of the gendered nature of colonial space, defines as the 'aesthetic of the sublime', where the immense 'landscape is seen solely in terms of a backdrop in the working out of a self-identity'. ${ }^{20}$ Given the island's condition of isolation and uninhabitedness, Rumiz cannot avoid the temptation of assuming the attitude of the explorer. This attitude manifests itself in his act of giving a name to a donkey he encounters on the island, when he remarks that 'chi va alla scoperta di un'isola, come tutti i conquistatori, prende il vizio di ribattezzare i luoghi e le creature che li abitano' (p. 31). Naming is an obvious act of asserting authority over something that has been discovered, and that, as such, can be claimed as a legitimate conquest. Here Rumiz reactivates old tropes of colonial writing, which run the risk of presenting a stereotypical and clichéd image of his narrative island. Yet, through a narrative re-mapping of his own Mediterranean experience, Rumiz manages to avoid conventional images and assumptions that seem at first to inform his journey. Thus, Il Ciclope succeeds in proposing an alternative characterisation of the island and the Mediterranean as a whole.

By asserting his intention of 'ubriacarsi di vento e di mito' (p. 22), Rumiz links together the two main elements that sustain his Mediterranean re-mapping. First, 'myth', in the Greek etymological meaning of the term, as 'story' and 'storytelling': Rumiz's narration of his experience on the island develops through the memories of other journeys that create links between the present-day Mediterranean and other spaces and times. Thus the layer of 'story space', which is, according to Ryan, Foote, and Azaryahu's narrative categorisations, 'the space relevant to the plot, as mapped by the actions and thoughts of the characters', extends far beyond the Mediterranean island. ${ }^{21}$ In his current Mediterranean journey, the author is learning 'il gusto della divagazione e del periplo' (p. 76), so that he constantly

\footnotetext{
${ }^{20}$ Sara Mills, Gender and Colonial Space (Manchester: Manchester University Press, 2005), p. 58. See, for instance, the following passage: 'La visione zenitale diceva di un luogo violento, estremo. [...] le sue piante uniche, $[\ldots]$ e l'aggressione degli odori [...]. Scopri che i fogli del tuo taccuino sono troppo piccoli per l'enormità che ti circonda, e troppo grandi per i tuoi miserabili pensieri' (p. 36).

${ }^{21}$ Marie-Laure Ryan, Kenneth Foote and Maoz Azaryahu, Narrating Space/spatializing Narrative: Where Narrative Theory and Geography Meet (Columbus: The Ohio State University Press, 2016), p. 24.
} 
strives to refocus his own physical and narrative trajectory. Only by digressing and going off at a tangent will the traveller/narrator ultimately be able to assess the significance of the island, both in itself and within the larger Mediterranean context to which it belongs.

The whole journey, and the narration of it, trace a multi-directional itinerary that starts in the 'enclosed' Atlantic Ocean of Pembrokeshire, which marks the first memory of a past journey, and ends in the enclosed Mediterranean - or more precisely the Adriatic - of Trieste, where Rumiz 'returns' after leaving the island. Between the two locations, the narrative moves through various Mediterranean sites in Italy and Greece, while also widening the coordinates of its trajectory by reaching Point Hope, in the extreme north of Alaska. Here, in the most disturbing finis terrae the writer has ever seen, 'tutto si capovolge,' including Europe, 'capovolta sulla mappa [...], tutto si inverte' (p. 83), so as to invalidate the dichotomy between North and South, Europe and the Mediterranean. The itinerary complicates any conventional and static view of the map, creating a space that, in De Certeau's terms, is a 'practiced place'. ${ }^{22}$ Narrative movement, as opposed to the static dimension of a descriptive overview, ceaselessly transforms places into spaces and vice versa.

The second instrument of Rumiz's Mediterranean re-mapping is the wind, the element that sustains the writer's back-and-forth narrative travel. As we have seen, the whole narrative journey moves constantly across space and time, oscillating between different points of departure and arrival. By doing so, it rejects a teleological approach, while embracing what Kamau Brathwaite describes as a 'tidalectics', which significantly evokes 'the movement of the water backwards and forwards as a kind of cyclic motion, rather than linear'. ${ }^{23}$ The narrative moves according to a rhythm characteristic of natural elements. In the author's own words: 'A ripensarci, mi rendo conto di non aver scritto io questa storia. Sono stati il vento e la marea.' (p. 14).

\footnotetext{
${ }^{22}$ Michel de Certeau, The Practice of Everyday Life (Berkeley: University of California Press, 1984), p. 117.

${ }^{23}$ Kamau Brathwaite, Conversations with Nathaniel Mackey (Staten Island, NY: We Press, 1999), p. 44.
} 
Winds, waves, and tides become companion-agents of Rumiz's narrative. ${ }^{24}$ Winds create frictions on the surface of the sea, making this surface rough and producing the oscillatory back and forth movement of the wave. And, although in the passing of the whole wave, through its crest and its trough, water particles do not go anywhere, they move in circles within the wave and transmit energy to succeeding water particles. Winds also influence the variations in sea level, thus contributing to the regular ups and downs of tides. The 'static movement' of the water particles in a wave, as well as the continuous back and forth movement of the tides, resonate with Rumiz's narrative journey within and beyond the island. Although, like a water particle in a wave, the writer does not move physically from his island, his narrative does move back and forth, mapping a non-linear trajectory across the different places and times he revisits. The author's current Mediterranean journey creates the necessary energy to produce a forward movement, to be transmitted to a potential Mediterranean future. Moreover, the back and forth movement of the waves enhanced by the winds sustains a narrative movement into the past of Mediterranean narrative itself. In Homer's Odyssey, where, as Elizabeth Schultz notes in her ecocritical reading of the poem, 'all that happens on earth or at sea happens in relationship to weather and to the day's cycle', ${ }^{25}$ the winds determine the vicissitudes of Ulysses' travel back to Ithaca, pushing his ship towards different places within the Mediterranean Sea. At the same time, the cyclical movement of the waves informs the rhythm of Ulysses' own narrative. Like the Odyssey, Il Ciclope too develops through a back and forth narrative movement between past and present and among multiple Mediterranean locations. Narrative and the Mediterranean are mutually

\footnotetext{
${ }^{24}$ For a reframing of Deleuze and Guattari's concept of 'agencement' see Vinciane Despret, 'From Secret Agents to Interagency', History and Theory, 52 (2013), 29-44. Despret suggests a reconsideration of the notion of agency beyond a conventional definition of it, based on 'subjective experience and autonomous intention'. If reframed as not necessarily intentional, rational, and premeditated, this agency reveals itself as much more extensively shared in the living world, and the polyphonic nature of Rumiz's Il Ciclope bears witness to it in narrative terms.

${ }^{25}$ Elizabeth Schultz, 'Odysseus Comes to Know his Place: Reading the Odyssey Ecocritically', Neohelicon: Acta Comparationis Litterarum Universarum, 36.2 (2009), 299-310 (p. 302).
} 
implied: the former enables the latter and vice versa, and the movement of the narrative both creates and is created by the movement of the Mediterranean itself.

\section{Rumiz's Real and Narrative Island}

Although Rumiz does not reveal the name of his Mediterranean island, the island still represents a specific interaction of time and space within the re-mapped Mediterranean of $I l$ Ciclope. The narrative experience of this tiny and unknown island at the supposed centre of the Mediterranean challenges any simplistic conception of the Mediterranean itself, putting into question binary oppositions between modernity and tradition, centre and periphery, local and global, land and sea. By embracing the apparent contradictions between the two poles of each of these binaries, Rumiz's Mediterranean island reveals itself as a potential space that comprises land and sea; a space that, while being localised, can also address global concerns, and that, from its supposedly marginal position in the global world, can become a centre of critical thinking and effective engagement.

The writer perceives and describes the island as a far-away desert rock. However, this apparently isolated location embodies a set of contradictions that annihilates the very possibility of either a real or a metaphorical distance from the surrounding world. 'Le piccole isole sono il paradigma delle contraddizioni. Le cerchi per scappare dal mondo, e il meteo ti sbatte al centro di un universo senza pace. Sono periferia e ombelico’ (p. 31).

The island nullifies the contradiction between movement and immobility, where the latter tends to be applied to a backward Mediterranean as opposed to a modern Northern Europe: 'Chi ha mai detto che su un'isola deserta non succede niente? Appena ti rilassi, qui tutto ti cambia sotto il naso. Il tempo muta a una velocità impressionante e con lui la luce, gli odori, la temperatura' (pp. 73-4). Far from being immobile, the island moves at a very fast pace. However, the island changes according to a kind of internally regulated movement, which cannot be recorded in narrative forms, being itself incommensurable with human time. 
Only when change on the island is imposed from the outside do we find the island and its inhabitants showing resistance to the 'liquid-ation' that change might carry with itself. The situation of the donkey, 'unico grande mammifero dell'isola' (p. 30) except for the lighthouse keepers, is exemplary in this perspective. The one-eyed donkey, to whom on their first encounter Rumiz assigns the name 'Kyklops' (p. 31), condenses in himself the contradiction between modernity and tradition, while also pointing to a possible way out of it. Dispensed from his duties after the arrival of the cableway, which nowadays carries the heaviest cargo, blind and ignored even by the lighthouse keepers, the old donkey is "prigioniero e al tempo stesso monarca della sua isola' (p. 32). An isolated and self-regulated life on the island has always meant for him freedom from rigid constraints. Apparently extending this freedom by relieving him from his duties, modernity has also, however, entrapped him in the very impossibility of performing his tasks. Nevertheless, he does not give up. Unlike his predecessor - the last female specimen that apparently killed herself in order to avoid a dishonourable old age - he keeps looking at the world with his one eye, carrying out his own gesture of hope and resistance. He is himself a Cyclops, a being whose apparent deficiency might actually signify an alternative way of looking at things. I will come back later to the meaning that the figure of the Cyclops assumes in Rumiz's narrative. Here I will just say that it is a figure of the potentiality of lack: the donkey/Cyclops' tragic destiny might not be an end in itself, but instead lead to a possible overcoming of its own preconditions. Significantly, the condition of the donkey applies to the lighthouse keeper, who also belongs to the island as both its prisoner and its king, and whose work has been reduced too by the advent of new technologies. Like the donkey, he does not flee from the island. Rather, he accepts it as neither a place of exile nor a kingdom, but a living space that constantly changes, requiring him to adjust and find different ways of acting in it.

The intrinsic condition of openness to the outside space that the island, as a small piece of land surrounded by water, guarantees, counterbalances the apparent isolation and 
self-containment of Rumiz's destination. If any island is 'the site of a double identity - closed and open', ${ }^{26}$ Rumiz's island is 'lontana da tutto eppure al centro di tutto' (p. 17). While not revealing the island's exact position, the author still feels the need to reassure his implicit reader of its actual existence by pointing to the fact that a spatial representation of it can be found on any Mediterranean map. Thus, the reader is required to exercise a double effort of imagination. S/he can picture the island by imagining a map that would in turn provide a cartographical image of the island itself. As Robert Tally explains in his geocritical approach to literature, 'in producing [his/her] representation of a world (that is, the narrative itself), the narrator also invents or discovers the world presented in the narrative. For readers, this narrative makes possible an image of the world, much like that of a map' ${ }^{27}$

In the literary cartography of Rumiz's island, notions of centre and periphery also lose their normative coordinates. While his island is notionally positioned at the centre of the Mediterranean, the indeterminacy of its location means that it can also be imagined and positioned on the map at any corner of the Sea, whose position, in turn, can be imagined both at the edge and at the very centre of the world map. Only in the narrative movement of its decentralisation can Rumiz's Mediterranean island also become a centre. Proposing an unconventional mode of Mediterranean thinking that would focus on the sea rather than on the land and apply cyber-theory to a renewed conception of the Mediterranean space, Miriam Cooke notes:

The islands that are geographically centred in the Mediterranean are rarely centres of power; rather, they are crossroads, sometimes sleepy but sometimes also dangerous places of mixing, where power is most visibly contested and where difficult choices must be made. These islands can be either centres or peripheries. The meaning attached to their location will depend on the

\footnotetext{
${ }^{26}$ Chris Bongie, Islands and Exiles: The Creole Identities of Post/colonial Literature (Stanford: Stanford University Press, 1998), p. 18.

${ }^{27}$ Robert Tally, Spatiality (London: Routledge, 2013), p. 49.
} 
subject position of the speaker, which in turn determines where the perimeter of the Mediterranean is drawn. ${ }^{28}$

In Rumiz's text, the position of the island, as well as that of the writer (the speaker) within it and of the reader of the text, is not fully specified, so that it ultimately remains open and unstable. Thus, Rumiz's narrative island, and all the different islands it might possibly represent, can be a periphery and a centre at the same time, as the island's undetermined but still localised space undoes the spatial opposition between the two.

In his study of creole identities in the post-colonial literature of the West Indies, Chris Bongie notes that 'every island is a fragment of the whole that is always already in the process of transforming the particular into something different from its original self'. ${ }^{29}$ Rumiz's island and the whole Mediterranean around it are mutually involved in a process of movement and change that participates, in its own terms, in the larger movement of change of the global world. By virtue of being at the same time a real and localised place - an island within the Mediterranean Sea - and an imaginary open space that refuses localisation, Rumiz's narrative island questions any easy polarisation of local and global, insofar as neither of the two terms can be fully realised here. Following Lyotard's suggestions, we can acknowledge that 'resistance lies in the little narrative, in locality and particularity', precisely 'because the local is where the global happens'. ${ }^{30}$ The dichotomy between local and global, then, loses its raison d'être, nullified by the phenomenon of a globalisation that implies both standardisation and proliferation of difference. In the contemporary globalised world, where 'fragments have acquired [...] new self-consciousness of their role in an increasingly visible totality', ${ }^{31}$ the apparent immobility of the local does not imply backwardness: it might be instead a form of resistance to a movement imposed from the outside.

\footnotetext{
${ }^{28}$ Miriam Cooke, 'Mediterranean Thinking: From Netizen to Medizen', Geographical Review, 89.2 (1999), 290300 (pp. 296-97).

${ }^{29}$ Bongie, p. 18.

${ }^{30}$ Mark Currie, Postmodern Narrative Theory, $2^{\text {nd }}$ edn (Houndmills, Basingstoke: Palgrave Macmillan, 2011), pp. 111, 112.

${ }^{31}$ Currie, p. 133.
} 
This form of resistance to globalisation by virtue of embracing - and turning into a strength - the apparent contradiction globalisation itself proclaims between stability and movement is particularly strong in the geographical space of the island, as Elizabeth Deloughrey's Routes and Roots - a comparative study of Caribbean and Pacific Island literatures - reveals. ${ }^{32}$ As the title of her book suggests, in the apparently isolated context of the island both 'routes and roots' need to be acknowledged and foregrounded, where 'refusal to migrate can be resistance to colonial trajectories rather than lack of cosmopolitanism'.33 Rumiz's island of Il Ciclope embraces this apparent contradiction between roots and routes, movement and stability, isolation and openness, the local and the global. The writer refuses to reveal the nation to which the island belongs since 'il mare non ha frontiere' (p. 17). As a transnational space, the Mediterranean Sea has always been a space of movement and exchange, 'è sempre stato dei migranti' (p. 127). If 'tutto il Mediterraneo è diventato frontiera' (p. 125) it is because it has surrendered to the binary simplification of a North/South divide, which the current rhetoric of a 'migration crisis' reinforces. Challenging a long-standing Eurocentric definition of the Mediterranean as Mare Nostrum, Rumiz highlights how the Latin expression needs to be interpreted not as 'mare di nostra proprietà', but as 'mare di tutti coloro che lo abitano' (p. 82), where inhabiting does not coincide with belonging. ${ }^{34}$ Rumiz instead acknowledges the impossibility of anyone fully belonging to the island, while the island remains open to what Derek Walcott has called 'the possibility of infinity. ${ }^{35}$ It is the infinity of possible belongings created by the parallel infinity of routes that converge and crisscross in the island's space. 'Essere del posto su un'isola disabitata e lontana da tutto è un concetto terricolo che mi fa impazzire. Qui nessuno è del posto’' (p. 101).

\footnotetext{
${ }^{32}$ Elizabeth DeLoughrey, Routes and Roots: Navigating Caribbean and Pacific Island Literatures (Honolulu: University of Hawai'i Press, 2007).

${ }^{33}$ Deloughrey, 'Island Writing, Creole Cultures', p. 816.

${ }^{34}$ For a philosophical revisiting of the concepts of inhabiting and belonging in the context of the contemporary Mediterranean migration see, Donatella Di Cesare, Stranieri Residenti (Torino: Bollati Boringhieri, 2017).

35 Derek Walcott and William Baer, Conversations with Derek Walcott (Jackson: University Press of Mississippi, 1996), p. 159.
} 
In Rumiz's narration the island performs a continuous movement between deterritorialisation and re-territorialisation. It does not abide by what Roberto Dainotto describes as 'un concetto di globalizzazione nomadica, senza centro e territorio - liquido, come osservava Bauman' ${ }^{36}$ On the contrary, from its own local territory, central and decentred at the same time, Rumiz's narrative island can tackle Dainotto's challenge, which 'non è più quella di deterritorializzare e liquefare, ma di ri-territorializzare'. Aware of the risks associated with a fluid conception of the Mediterranean that recalls the fluidity of Bauman's 'liquid modernity', Dainotto asserts the necessity of identifying 'specifici agenti umani e sociali, non il mare, come soggetti storici e veicoli di una nuova utopia', which would resist the fluid movement of a homogenising globalisation. The local but non-localised island of $I l$ Ciclope manages to propose an alternative kind of agency, where human and non-human forces can coexist and work together, insofar as both the donkey and the lighthouse keeper can be parallel agents of resistance.

Thus Rumiz's island overcomes the dichotomy between fluid and solid, pointing instead towards a possible coexistence of the two in the form of integration between land and sea. In the local language, the centre of the island, Rumiz has been told, gets its name from a lizard or salamander (p. 44). The writer does not suggest any specific meaning for the name, nor does he report any story that would explain it. However, the lizard commonly symbolises regeneration, adaptability, strength and resistance, while the salamander was in ancient times thought to be able to resist fire. Both animals are cold blooded, which means that they are particularly able to adapt to their environment by taking on the outside temperature. While the lizard is a reptile, the salamander is an amphibian, hence a water dweller. ${ }^{37}$ By getting its

\footnotetext{
${ }^{36}$ I am quoting from Roberto Dainotto's keynote address entitled 'Mediterraneo, Liquido e Solido', given at the conference 'Echi d'Oltremare: L'Italia, il Mediterraneo e oltre', on June 17, 2011 in Rome. His main point of reference here is to Zygmunt Bauman, Liquid Modernity (Cambridge: Polity Press, 2000).

${ }^{37}$ For an 'amphibian' approach to Mediterranean ecocriticism, see Serenella Iovino, 'Mediterranean Ecocriticism, or, A Blueprint for Cultural Amphibians’,Ecozon@4.2 (2013),1-14.
} 
name from these two creatures at the same time, the centre of the island embraces hybridity as a form of resistance that combines the forces of earth and water.

If the lizard and the salamander are symbolic personifications of the core of the island, then the island as a whole can be seen as a site that pursues the ultimate integration of land and sea. The desert rock of the island adapts to a Mediterranean Sea that does not simply surround it, but also plays a part in shaping it. The geographical mass of the land constantly renegotiates its condition within the mass of water to which it belongs, in a relationship of mutual exchange. Thus, Rumiz's island is a narrative example, real and imaginary at the same time, of what Philip Hayward has called 'aquapelagos', a concept elaborated as a critique of the common orientation in Archipelago Studies. Where the latter sees aquatic realms as 'watery spaces between and connecting land masses', aquapelagos, on the contrary, are 'entities created when humans occupy and interact with integrated island and aquatic spaces' ${ }^{38}$ While Hayward initially used the concept to describe the assemblage of land and water masses within a group of islands, he later applies it also to single islands characterised by the interactivity of humans with an environment that is both terrestrial and aquatic. Christian Fleury, building upon Hayward's definition of the aquapelago, also links it to the concept of 'maritory'. A group of French geographers first coined the term 'maritory' to emphasise the three-dimensionality of sea space, which better reveals its close relationship with land. In his geographical study of the territorialisation of marine spaces, Fleury suggests that islands are 'intermediate spaces' between land and sea, where the delicate and precarious integration of the two is most evident, while also being constantly renegotiated. ${ }^{39}$

The geographical and geo-social concepts of the aquapelago and the maritory, which presume the combination and interaction of human and non-human, as well as terrestrial and

\footnotetext{
${ }^{38}$ Philip Hayward, 'The Constitution of Assemblages and the Aquapelagality of Haida Gwaii', Shima: The International Journal of Research into Island Cultures, 6.2 (2012), 1-14 (pp. 1, 2).

${ }^{39}$ Christian Fleury, 'The Island/Sea/Territory. Towards a Broader and Three-dimensional View of the Aquapelagic Assemblage', Shima: The International Journal of Research into Island Cultures, 7.1 (2013), 1-13, (p. 11).
} 
aquatic, elements, suit the space of Rumiz's island. Here, the life of the only human inhabitant

- the lighthouse keeper -fully depends on the life of the sea, which in turn is determined by the changing combination and constant interaction of natural elements, like winds and waves. This constantly evolving interaction and the possibility of an integration never to be fully achieved are also responsible for the movement of the narrative, hence significantly contributing to the narrative ecosystem of the island itself. As in the archetypal Mediterranean journey of the Odyssey, where the winds, by determining Ulysses' journey back to Ithaca, also guarantee the narration of it, in Il Ciclope too winds and waves sustain Rumiz's physical and narrative journey.

\section{The Ultimate Resistance of the Lighthouse}

Rumiz's narration of his Mediterranean 'adventure' starts in medias res, as the book opens with the author/narrator landing on the unknown island, which he recalls as if occurring in a dream. The first contact with the island is threatening and frightening. The fury of the elements, the absence of any human presence, and the darkness that impedes a clear view of the surroundings all contribute to an initial sense of uneasiness and danger:

Era quella che si dice una nottataccia. Salivo per il sentiero a picco sul mare lottando con le raffiche, e nel buio dovevo badare a dove mettere i piedi. Da ovest arrivava il temporale, $[\ldots]$ Ero solo, non conoscevo la strada del faro e l'Isola era deserta. Miglia e miglia lontano, il resto dell'arcipelago era inghiottito dal buio e dalla spruzzaglia. Non una luce, niente. (p. 11)

Rumiz's condition upon his arrival on the island, as well as the state of the island itself, cannot help but remind the reader of the Odyssey. More specifically, given the title of Rumiz's book, the writer's narrative landing on the Mediterranean island recalls Ulysses' landing on the island of the Cyclopes. As part of the larger narration, at Alcinous' court, of his adventurous return to Ithaca at the end of the Trojan War, Ulysses remembers the 'dark night' in which he landed, together with his companions, on an unknown island. Winds are 
responsible for this further delay in Ulysses' trip back to Ithaca. Just when the winds seem to facilitate the helmsman's steering of the ship and accelerate the way back home, Boreas comes and alters the route, as Tramontane does in Rumiz's narrative. ${ }^{40}$ Moreover, Ulysses narrates how a thick mist and the absence of moonlight prevent the Greek heroes from even seeing the island before they actually land on it. Like Rumiz on his arrival, they are left in darkness, and suspended in a condition of uncertainty. ${ }^{41}$

While retracing Ulysses' landing on the island, Rumiz actualises but also reinvents Ulysses' adventure with the Cyclops, providing it with a new meaning in the contemporary space of the Mediterranean. If the figure of the Cyclops reveals Rumiz's indebtedness towards the Homeric narrative, it also refers to the lighthouse, 'Ciclope di pietra' (p. 39) built on the island itself. In Rumiz's narrative, the Cyclops and the lighthouse are two sides of the same coin. Rumiz spends most of his time in this ultimate bastion of human presence on the island, interacting to a greater or lesser extent with the different keepers. A positive and negative symbol at the same time, the Cyclops/lighthouse condenses the contradictions of the island and of the whole Mediterranean space to which it belongs. Ultimately, the Cyclops/lighthouse points towards a Mediterranean alternative that lies in the struggle for adaptation and negotiation of one's own position within the larger world.

From the beginning of the narrative, the lighthouse appears as an ambiguous space. It is definitely a shelter from the threatening conditions of the island and the sublime nature that rules over it on the night when Rumiz arrives from the sea. Thus, it feels reassuring and familiar, providing the writer with light and the illusion of a dwelling in the middle of a dark night on the Mediterranean Sea. As the reference to 'Giona' in the title of the first chapter of

\footnotetext{
${ }^{40}$ In the chapter Tramontana (pp. 23-26), Rumiz narrates the play of the winds that sustain the movement of the Mediterranean Sea. When 'levantazzo', the harsh and desertic wind that comes from the east, is over, the dead calm sea of 'bonaccia' lasts for a few hours before 'scirocco' suddenly reactivates movement. The further return of 'bonaccia' ultimately resolves itself into the arrival of a northern wind, tramontane, 'più costante, meno nervosa' (p. 24), a wind of strong and enduring resistance.

${ }^{41}$ See Homer, The Odyssey of Homer, trans. by Richmond Lattimore (New York: Harper Perennial, 1999), book IX.
} 
the book suggests, the lighthouse is also Jonah's whale from the biblical story. As such, it is a space that saves life, offering a defence against the power of winds and waves. At the same time, it swallows up and takes over human life. 'Fuori rinforza, gira da Scirocco a Libeccio. Sono nella macchina di luce, nella sua pancia, come Giona nella balena. La prima notte nel faro non è ancora finita, e il Ciclope si è già impossessato di me' (p. 12). While inside of the whale's belly, Jonah is supposed to clear his mind and gain an awareness of his duty as a prophet. Similarly, the lighthouse can provide Rumiz with a better perspective on the Mediterranean world he intends to narrate, thus enhancing his own 'narrative duty'. The lighthouse can be both the point of departure and the destination of a renewed narrative journey across the Mediterranean itself. ${ }^{42}$

However, when Rumiz first looks at it, the lighthouse also appears frightening and threatening. 'Cercava l'intruso con l'unico occhio da ciclope. Sfolgorava, ma proprio la fonte di luce era buia come la pece, più nera della notte stessa. Era irata e mi stava cercando' (p. 11). The lighthouse is the Cyclops, the enormous, 'horrendous monster' of Ulysses' story. It is the Cyclops who treats Ulysses and his companions as intruders rather than guests, and who, at the end of Ulysses' short stay in his cave, furiously looks for him in vain. It is not by chance that Rumiz perceives the acute feeling of ephemerality that the lighthouse communicates, a 'senso di vulnerabilità di queste torce assediate dai marosi, dalle guerre, e dall'incuria degli umani' (p. 46). Despite his great physical strength and his undisputed rule over the island, Polyphemus is also a figure of vulnerability. He cannot in the end prevent Ulysses' deceit and gets hurt in the most vulnerable part of his body - his only eye.

This vulnerability that the Cyclops/lighthouse shows in Rumiz's narrative further complicates the possibility of a clear distinction between its positive and its negative connotations, reaffirming the ambiguity of the whole figure/symbol. Like the donkey and the

\footnotetext{
${ }^{42}$ At the end of his time on the island, Rumiz goes back to Trieste, and as soon as he enters the apartment and gets a glimpse of the sea from his balcony, he realises that his house too 'è un faro' (p. 145), a point of arrival and of departure.
} 
lighthouse keeper, the lighthouse is both king and prisoner of its Mediterranean island. This condition further aligns it with the Homeric Cyclops from which Rumiz's narrative takes its name. Polyphemus, in Ulysses' story, is undoubtedly the ruler of his own life on the island, and of the island itself, so powerful he is not even afraid of the Gods. And yet, he ends up being fatally entrapped in his own island for the rest of his life, once Ulysses has blinded him.

It is necessary to note, at this point, that in Rumiz's narrative neither the destiny of the lighthouse nor that of the donkey has the tragic dimension of Polyphemus' fate in the Greek narrative. The electric eye of the lighthouse and the only functioning eye of the donkey have not been reduced to blindness, as was the case with Polyphemus. In the narrative dimension of Rumiz's Mediterranean, the lighthouse and the donkey keep looking ahead, towards a future yet to be written, with their only eye - a deviation from the norm that, as already discussed, opens up the potential of an alternative way of seeing.

What role, then, does Rumiz assign in his narrative to the figure of a contemporary Ulysses, who has to negotiate his position in relation to the lighthouse/Cyclops within the space of the Mediterranean island he temporarily inhabits? Rumiz explicitly draws a parallel between the Greek hero and the lighthouse keeper, at the moment when the latter arrives on the island in order to take practical and symbolic possession of the building. 'E poi arrivare dal mare non è un arrivare qualunque', the writer notes, and compares the newcomer to 'Ulisse dritto sulla prua della sua nave mentre i compagni vogano nel mare color del vino' (p. 95). If the island on which the lighthouse keeper lands is Ulysses' island of the Cyclopes, then Rumiz's narrative is suggesting a post-anthropocentric revisiting of the Odyssey. The lighthouse keeper/new Ulysses needs to learn how to live on and with the island, constantly renegotiating his own role not in order to deceive the Cyclops but to find a way to coexist with him. Also, the writer highlights the peculiar condition of the islander, who, while waiting for someone else's arrival from the sea, is himself/herself at sea, moving 'su qualcosa che equivale a una nave' (p. 96). Thus, Rumiz's Cyclops/lighthouse keeps moving within the 
endless movement of the whole island on which he lives. Rumiz's Cyclops is no longer imprisoned in the only apparent freedom of his rule but is himself open to the possibilities that come from the surrounding world, within and beyond the sea.

When analysing the rewriting of the Homeric episode in Il Ciclope we finally need to pay attention to the fact that Rumiz has experienced and narrated his own arrival on the island from the sea. The new Ulysses might well be the narrator himself, then, or indeed the narrative protagonist of Rumiz's tale. When the character Rumiz confronts the Cyclops on the latter's island, he must reformulate his own identity in order to survive, as Ulysses does by telling Polyphemus that his name is 'Nobody'. However, Rumiz neither lies to the Cyclops/lighthouse that both hosts and frightens him, nor completely renounces his identity. Rather, he re-maps and rearticulates his own space within the larger space of the Mediterranean island to which he travels. By doing so, Nobody/Rumiz does not earn, as Ulysses does, the sarcastic and inhospitable gift of being eaten last. He does not inherit the 'anthropocentric blindness' that, as Schultz notes, leads Ulysses, 'blind to the environment and to the lives of others', to the 'savage blinding of Polyphemus'. ${ }^{43}$ On the contrary, Rumiz accepts the gift the island offers him of decentring himself from his own real and narrative world.

In Homer's narrative, Ulysses eventually escapes from the menacing Cyclops by hiding under the long thick fur of a ram. Polyphemus addresses the ram, who for the first time exits the cave last, wishing the creature could speak and tell him where Ulysses is. But animals, in the Greek narrative, are mute, and they do not seem to take the side of either of the two contenders. For Ulysses, in particular, animals are pure instruments, to be used to his advantage. They cover and hide the shape of the human, like the wooden horse in the Iliad that Ulysses himself designed. In the dramatic encounter between Ulysses and Polyphemus, the animals allow the Greek heroes to escape from the cave and ultimately to deceive the

\footnotetext{
${ }^{43}$ Schultz, pp. 305, 306.
} 
Cyclops. However, Ulysses' final sacrifice of the ram to Zeus proves useless in appeasing the Gods, so that 'it is apparent that the animal is killed unnecessarily, wastefully' ${ }^{44}$ In Ulysses' adventures, animals are either fake, simulacra, or mute and passive witnesses of human actions. As a new Ulysses, Rumiz reinvents the Cyclops' island so as to point instead towards a deep awareness of the human's relationship with the surrounding world, and all that it contains. At the moment of his escape from the Cyclops' land, 'l'asino guercio tentò di ragliare per salutare, ma non ci riuscì. [...] L'isola stessa sembrava un raglio muto, [...] salutava senza dire nulla' (p. 143). The silence of the donkey, and of the whole island with him, differs from both the mute passiveness of Polyphemus' ram and the blinded Cyclops' final shouting in the Odyssey. This ultimate silence is, rather, the actual voice of the Mediterranean island to which Rumiz has learnt how to listen, and which does not require human language in order to communicate.

\section{Conclusion}

What kind of Mediterranean space does Rumiz's narrative journey ultimately map? This is not a circular itinerary, in the same way as Ulysses' journey is only apparently circular. The digressive structure of Rumiz's physical and narrative journey might be closer to what Edward Said has described as a 'circularity of structure, inclusive and open at the same time' ${ }^{45}$ At the end of his time on the island, Rumiz does go back to his hometown, Trieste. However, within the space of the writer's narrative journey, Trieste does not figure as a point of departure since the tale, as we have seen, starts with the writer/narrator/character already on the island. And although Trieste is the place when the narrative ends, it is intended, just like Ulysses' Ithaca, only as a temporary stop within a further physical and narrative movement, as the closing sentences of the book make clear: 'Avevo voglia di far riposare le

\footnotetext{
${ }^{44}$ Schultz, p. 306.

${ }^{45}$ Edward Said, Culture and Imperialism (New York: Vintage Books, 1994), p. 189.
} 
mie vecchie ossa, ma non c'era requie. La luce già indicava un'altra meta' (p. 147). Itself a borderline and unstable location, Trieste can only be a point of arrival and departure at the same time, along with all the other narrative spaces Rumiz has revisited throughout his 'Cyclopean' journey.

By means of his physical and narrative journey within the space of the island, Rumiz recovers the complexities of the whole Mediterranean space, within the larger complexity of the global world. Rumiz's island narrative allows one to experience and revaluate the contradictions that this Mediterranean space entails, being at the same time, as we have seen, a local and a global space, a centre and a periphery, and a space where land and sea, human and non-human can and must ultimately coexist and adapt to each other.

It does not matter, in the end, if the narrative is only an imperfect representation of the actual geo-space of the Mediterranean. What does matter is that this narrative can be useful in revising one's own way of seeing and interpreting that space itself, allowing for what Tally calls an 'exercise of literary geography'. ${ }^{46}$ If so, Rumiz's Mediterranean - with its one-eyed Cyclops/lighthouse figure - can also suggest alternative ways of looking at the world at large, insofar as we believe that 'the reader of narrative maps draws upon frames of reference to help make sense of both the text, the space it represents, and the world' ${ }^{47} \mathrm{Il}$ Ciclope, then, promotes a new understanding of the potential role of the Mediterranean as a whole in the present as well as in the future. Whereas the East/West dichotomy within Europe, which lies at the core or Rumiz's earlier production, seemed at that time to be an insurmountable barrier, the Mediterranean that emerges in Rumiz's latest work points towards a possible overcoming of conventional geographical binaries. Rumiz's alternative Mediterranean, then, does not need

\footnotetext{
${ }^{46}$ Tally, p. 85 .

${ }^{47}$ Tally, p. 85.
} 
to be in contrast with Europe. Rather, it can be a space from where Europe itself might be reimagined. $^{48}$

${ }^{48}$ My closing suggestion here is indebted to Massimo Cacciari's geophilosophy of the Mediterranean, which highlights the Mediterranean's potential for reimagining Europe as a whole: 'L'Europa di cui oggi si parla [...] deve avere al suo interno una dimensione Mediterranea.' (Massimo Cacciari, 'Non potete massacrarmi Napoli', in La Città Porosa: Conversazioni Su Napoli. Napoli, ed. by Claudio Velardi (Naples: Cronopio, 1992), pp. 15790 (p.161). 